\title{
Protecting Employees' Wages in Accordance with Saudi Labour Law: Should We Do More?
}

\author{
Meshal Nayef Alharbi \\ Department of Law, College of Science and Theoretical Studies, Saudi Electronic University, Saudi Arabia \\ Email: meshalna@yahoo.co.uk
}

How to cite this paper: Alharbi, M. N. (2021). Protecting Employees' Wages in Accordance with Saudi Labour Law: Should We Do More? Beijing Law Review, 12, 320341.

https://doi.org/10.4236/blr.2021.122019

Received: February 26, 2021

Accepted: April 10, 2021

Published: April 13, 2021

Copyright (อ 2021 by author(s) and Scientific Research Publishing Inc. This work is licensed under the Creative Commons Attribution International License (CC BY 4.0).

http://creativecommons.org/licenses/by/4.0/

(c) (i) Open Access

\begin{abstract}
The Saudi government intends to enhance the private sector working environment and to make it more attractive to potential employees by establishing rules and programs like the Wages Protection System, which aims to monitor procedures for paying employees' salaries; a private company will be founded in the near future for the same reason. This paper examines the rules for paying employees' wages in the private sector, in particular, the issue of not paying their wages by the date due, and how the Saudi Labour Law and the Wages Protection System deal with the issue, to reveal whether there is a need to reform the current approach. The paper analyses mainly legal materials related to Saudi Labour Law such as books, the courts judgments published by the Commission for the Settlement of Labour Disputes in Saudi Arabia and relative information provided on the web sites of The Ministry of Human Resources and Social Development. In brief, this study suggests amending the current approaches relevant to this issue, as there are various weaknesses and concerns that have been identified in the approaches adopted in Saudi Labour Law to dealing with the delayed payment of workers' salaries.
\end{abstract}

\section{Keywords}

Saudi Labour Law, Employees' Wages, Delayed Wages, Wages Protection System, Employee Rights

\section{Introduction}

Saudi Arabia is one of oil-rich states that are considered "a region with exceptionally high international migration of persons originating from a wide range of countries" (Shah, 2008). The fact is that historically, non-Saudi labourers "are almost exclusively employed in the private sector" (The US-Saudi Arabian Business Council, 2017). Also, although the Saudi government has introduced the 
Saudization program which aimed to encourage the native population to work in the private sector (Asian Development Bank Institute; Organisation for Economic Co-operation and Development; International Labour Organization, 2019), it still continues to rely heavily on the foreign workers. The General Authority for Statistics estimates that migrant labourers made up approximately $77 \%$ of the private sector's labour force in Saudi Arabia (The General Authority for Statistics, 2019). The fact is that the Saudi Labour Law shall govern employment agreements between the non-Saudi labourers and the employers in the private sector. In this context, Section 1 of Article 39 of the Law regulates the possibility of allowing a non-Saudi labourer to work on behalf of another employer and states that "unless he has followed the stipulated legal rules and procedures, an employer may not allow his worker to work for others, and a worker may not work for other employers. Similarly, an employer may not employ workers of other employers". Also, Section 2 of the Article establishes the provision that "an employer may not allow a worker to work for his own account and a worker may not work for his own account". These rules mean logically that employment salaries are the main or, in most cases, only source of income for the non-Saudi workers, and therefore, non-payment or delay in payment of their wages due under the employment agreements will raise many concerns and questions.

On 25 April 2016, the Saudi government announced Saudi Vision 2030, its vision for enhancing life in Saudi Arabia, which aspires to achieve various goals through the cooperative efforts of governmental ministries and bodies (The Saudi Council of Economic and Development Affairs, 2018). The Ministry of Human Resources and Social Development designed eleven goals "to meet the ambitious national vision"; one of the main targets is to "create a safe and attractive working environment" (The Ministry of Human Resources and Social Development, 2020a). The sixth dimension of the National Transformation Program 2018-2020 seeks to empower all groups in society to access the labour market and to make the market more attractive. Strategic objective No. 4.4.2 of this dimension aims, in general, to improve private sector working conditions for employees by promoting and protecting their rights, both financial and otherwise (The Saudi Council of Economic and Development Affairs, 2018). Furthermore, the Operational Plan for the National Transformation Program 2018-2020 reports that a private company will be founded to institute an effective system for managing wages and salaries to increase transparency and securely protect the rights of employees and employers (The Saudi Council of Economic and Development Affairs, 2018). On 4 July 2019, it was announced that this private company will be launched at the end of 2020 to manage the wages of employees, regardless of their nationality, in the private sector in Saudi Arabia (Almutairy, 2019). Labourers' salaries and other information will be registered with this company, which will maintain the data with a high rate of accuracy and validity; the company will then refer the information to the Ministry of Labour ${ }^{1}$ and the General Organisation for Social ${ }^{1}$ Its name has been adjusted to the Ministry of Human Resources and Social Development by the Royal Decree No A/455 on 25 February 2020. 
Insurance. The company's objective will be to make private sector institutions more attractive for job seekers who wish to work for establishments with highly regulated wage payment procedures (Almutairy, 2019).

The protection of employees' wages has received significant attention this decade in Saudi Arabia ${ }^{2}$. On 1 June 2013, the Ministry of Human Resources and Social Development launched the Wages Protection System to monitor salary payment processes for all private sector employees, regardless of their nationality or gender. This program, which went into effect on 1 September 2013, was applied gradually to all private sector companies, regardless of size, based on the number of labourers employed and every company that employed from 1 to 4 workers was required to enrol in this scheme by 1 December 2020 (The Ministry of Human Resources and Social Development, 2020b). This system enables the Ministry of Human Resources and Social Development to determine the degree to which private sector establishments are disciplined in paying their employees' salaries on time and consistent with the amount agreed to by the parties to the relevant employment agreements (The Ministry of Human Resources and Social Development, 2020b). The program also assesses whether paid wages are equal to the wages enrolled, by comparing the data registered in the Wages Protection System with the database of the wages payment file and the information of the General Organisation for Social Insurance (The Ministry of Human Resources and Social Development, 2020b). To apply this system properly, the establishments must pay labourers their wages by transferring the funds to their workers' bank accounts (The Ministry of Human Resources and Social Development, 2020b). The payment documents are rejected if the wages are paid by a foreign currency (The Ministry of Human Resources and Social Development, 2020b). This process is concordant with Sections 1 and 2 of Article 90 of the Saudi Labour Law, which provides that institutions are compelled to pay their workers' wages with Saudi currency and through their employees' bank accounts, accredited in Saudi Arabia, on the due dates.

The Wages Protection System establishes additional rules related to paying workers' wages in Saudi Arabia. For example, in cases when the basic wages of the employees that are submitted to the system are not equal to what has been registered in the General Organisation for Social Insurance, the employer shall be punished. The information that must be submitted and registered each month, according to the Wages Protection System, is as follows:

The net wage that would be transferred or deposited in the employee's account. The employee's account number. The employee's name. The name of the bank that contains the employee's account. The description of the remittance. The amount of the basic salary. The amount of the housing allowance. Other allowances. Total amount of deduction. The employee identity number (the identity card or the Iqama). The remittance process

${ }^{2}$ On 25 August 2020, the Saudi Council of Ministers has approved the Protection of Wages Convention, 1949 (No. 95). 
number. The status of condition of the transferring process. The date of the transferring process (The Ministry of Human Resources and Social Development, 2020b).

The program provides huge benefits for labourers, employers, the community, the national security and the economy $y^{3}$. According to The Ministry of Human Resources and Social Development statistics, at the end of 2017, a total of 42,418 establishments, employing 6,154,636 labourers, were enrolled in this system (Al Riyadh Newspaper, 2018).

On 07 February 2019, it was reported that an employer in Saudi Arabia failed to pay the wages of 80 employers for 12 months although the Commission for the Settlement of Labour Disputes issued a final judgment to require the employer to pay their wages (Alzahrani, 2019). Also, as cited in the Ministry of Human Resources and Social Development statistics announced on 12 October 2017, approximately $30 \%$ of establishments were not in compliance with the rules of the Wages Protection System (Badewilan, 2017). More detailed statistics on the nature of offences committed by the establishments raise the question as to how effectively Saudi Law addresses cases in which employers do not pay employees their wages according to the due date agreed to by the parties in the relevant employment contracts. This significant query has not yet received adequate scholarly examination although there are many academic books and materials that have been published in which the authors examine and detail in general the principles enacted in the Saudi Labour Law. Also, there are theses that examine mainly the rules for paying and protecting employees' wages in the private sector in Saudi Arabia that have been established in the Saudi Labour Law. For example, a thesis entitled The Legal Protection for Wage in Saudi Law, authored by

\footnotetext{
3"The Benefits of the Program: For the private sector laborers: The laborer ensures receiving his wage or salary on time \& with the amount agreed upon without any delays, cheatings or fraud. Avoiding the disparity in the data registered by the employer from what has been previously agreed upon and is normally paid. Proving the employee's rights through the transparent information of the wages, and an approved wages data reference in case there are any disagreements regarding the wages. For the employer (the establishment owner): Reducing the labor disagreements or troubles and providing a healthy work environment which encourages increasing the productivity. Making the labor dues or accruals on top of the priorities of the employer. Proving the payment of the labor wages without needing the receipt payrolls, and to retrench the malicious complaints. Providing the required precise information in order to enable the ministry of labor to release or publish statistics \& data about the labor market in a way that serves all the parties including the employer himself(the establishment). Increasing the competitiveness in the labor market and attracting the national cadres or staff. For the community: Providing a level of social welfare, psychological settlement or reassurance and a safe work environment. Ensure providing the social protection to all the private sector employees after retirement and in case of injuries via the compliance of the wages data registered in social insurances to the actual wages. For security: Controlling the foreign labor wages and linking them with what suits the labor contracts in addition to evaluating the suspected banking cases. Reducing the risks and the thefts cases resulting from paying the labor wages in cash money. For economy: Contributing in increasing the productivity of the labor in the private sector because of ensuring his rights. Providing the opportunities of establishing economic entities and jobs for the Saudi citizens through retrenching the fictitious employers, the foreign loose or abandoned labor and the labor concealment. Providing actual or real updated information and data which reflects the condition of the private sector and its future requirements." (The Ministry of Human Resources and Social Development, 2020b).
} 
Ben Ghunaim (2000). Another dissertation called The Wage in Saudi Labour Law, written by Almuzaini (1989). The third thesis entitled The Wage in the Employment Contract: A Comparative Study, authored by Alolyan (1988). However, they investigated the provisions established in the previous Saudi Labour Law in 1969 and did not provide a direct and detailed examination relating to the point of how Saudi Labour Law deals with issue of not paying employees' wages on the due date. Therefore, this research is undertaken to evaluate the approach upheld by Saudi law regarding the delayed payment of labourers' wages.

The main question guiding this study is whether the rules enacted in the recent Saudi Labour Law and the Wages Protection System satisfactorily address situations in which an employer does not pay a labourer's wages on the due date in accordance with conditions agreed to by the parties in their employment agreement. To fully examine this issue, several points are considered, as presented in this article. Firstly, the main rules established in the Saudi Labour Law that protect workers' wages are briefly reviewed. Secondly, recent approaches applied in Saudi law to deal with employer delays in paying workers' salaries are illustrated. Thirdly, legal flaws involved in the approach adapted in the Saudi Labour Law and the Wages Protection System are demonstrated. Then, appropriate approaches to be integrated into the Saudi law are suggested. Finally, this paper concludes with remarkable findings and recommendations for future studies.

\section{The Rules of Protecting Employees' Wages in Saudi Labour Law}

For employees, wage is one of the most significant components in the employment agreement. This fact is confirmed in Article 50 of the Saudi Labour Law, which defines the work contract as "a contract concluded between an employer and a worker, whereby the latter undertakes to work under the management or supervision of the former for a wage". Thus, the Saudi Labour Law does not govern any employment relationship in which the labourer agrees to perform specific work without being paid a wage (Bani Khalaf, 2018). For the vast majority of labourers and their families, employment wages are the main or only source of income. For this reason, Labour Laws give wages special protection (Hamdan, 2009; Hadfy, 2015). In addition, as salary is one of the main elements in work contracts (Hamdan, 2009), the parties to employment agreements must agree on the wage explicitly or implicitly (Hadfy, 2015). Consequently, salary is referred to as the bone of life, and if salary is not paid according to schedule, workers and their families' lives are likely to be negatively affected.

In general terms, Saudi Labour Law intends to protect employees' financial rights, including wage-related rights, and various provisions have been legislated for this purpose. For example, Article 59 of the Law rules that employees who receive their wage monthly shall not be reclassified as hourly, weekly or daily paid or as salary paid by piecework, unless this transformation is agreed to in 
writing by the employee and "without prejudice to the rights he has acquired during the period he spent as a monthly paid worker". The Superior Commission for the Settlement of Labour Disputes affirmed this rule in judgment No. 1389/1/432 issued on 3 October 2011 (The Code of the Labour Principles and Judgments 2011: pp. 187-194). In addition, Article 18 of the Saudi Labour Law establishes the mandatory principle that when ownership of an establishment is transferred or its legal form is changed by "merger, partition or otherwise", the successor and the predecessor will be liable jointly and severally for meeting employees' financial rights that existed before the legal transformation. Also, in general terms, Saudi Law secures the financial rights of employees and considers them as privileged debts in cases when an employer company claims bankruptcy or if the firm has been liquidated. In such circumstances, the rule established in Article 19 of the Saudi Labour Law that protects the financial rights of the workers is applied, as it states that these rights will be regarded as privileged debts, and the employees must be paid a certain amount of money "equivalent to one month [sic] wage prior to payment of any other expenses including judicial, bankruptcy or liquidation expenses". Furthermore, Article 89 of the Saudi Labour Law entitles the Council of Ministers to regulate minimum wage rules for employees, if necessary, based on a proposal introduced by the Minister of Human Resources and Social Development. Moreover, Article 92 sets the general principle that it is illegal to deduct any amount of money from a labourer's salary against private financial rights without his or her written approval, except in certain specified cases, such as when a competent forum has determined the debt, which must not exceed $25 \%$ of the worker's monthly salary, unless the forum decides otherwise 4 . In addition, Section 1 of Article 94 of the Saudi Labour Law establishes the rule that when an employer deducts any sum of a worker's wage without valid justification as identified in the Saudi Labour Law and without the approval of the employee, the competent authority shall oblige the employer to refund the wrongfully deducted amount. Additionally, Section 2 of the Article states that when the forum concludes that no valid reason existed to justify deducting said amount, it may fine the employer a certain amount of money "not exceeding twice the amount deducted from the worker's wage or twice the outstanding wages". Furthermore, according to Article 70 of the Saudi Labour Law, the employer is prohibited from deducting from a worker's wage, for payment of fines, an amount of money equal to more than five days' wages during one month's time. Further, the employer is not allowed to suspend an employee

${ }^{4}$ Article 92 of the Saudi Labour Law provides that “[n]o amount shall be deducted from the worker's wages against private rights without his written consent, except in the following cases: 1) Repayment of loans extended by the employer, provided that such deductions do not exceed $10 \%$ of his wage. 2) Social insurance or any other contributions due on the workers as provided for by law. 3) Worker's contributions to thrift funds or loans due to such funds. 4) Installments of any scheme undertaken by the employer involving home ownership programs or any other privilege. 5) Fines imposed on the worker on account of violations committed, as well as deductions made for damages caused. 6) Any debt collected in implementation of a judicial judgment, provided that the monthly deduction shall not exceed one quarter of the worker's wage, unless the judgment provides otherwise. First to be collected is alimony, followed by food, clothing and accommodation debts, before other debts". 
from work without pay for more than five days in a month. Moreover, Article 97 of the Saudi Labour Law forces the employer to pay $50 \%$ of the labourer's wage in cases when the worker has been detained "or taken into custody by the competent authorities" for issues "related to work or occasioned by it". In such circumstances, the employer must continue paying this amount to the labourer until the issue is settled, provided that the period of arrest or custody is not more than 180 days and the employer is not obliged to pay any sum of money for more than the stated period of time. The Saudi Labour Law further requires the employer to return the portion of wages that was deducted to the employee if the employee is cleared of all charges or if the issue is dismissed due to a lack of evidence or because the accusation is deemed invalid. Also, Article 62 of the Saudi Labour Law provides that in cases when employees are present at the workplace and express their readiness to perform their work duties at the scheduled time but are "prevented from doing so only by a cause" related to the employer, they are legally entitled to obtain "the wage for the period during which no work is performed". Finally, Article 88 of the Saudi Labour Law regulates situations in which the employment agreement has been terminated, stating that an employer who ends an employment contract must pay the employee the amount he or she is entitled to a maximum of one week from the date of the termination and within two weeks from that date if the agreement is terminated by the employee.

Based on the previous brief examinations, it has been shown clearly that the Saudi Labour Law contains proper rules to protect the employees' wages, but it is significant to illustrate how the Law handles the issue of not paying their wages on the due date.

\section{The Approach for Handling Delay in Payment of Employees' Wages}

The Saudi Labour Law includes various rules regarding employee wage payment delays. Section 1 of Article 81 of the Saudi Labour Law establishes the principle that employees have the full right to leave their work without notice and without harm to their statutory rights "if the employer fails to fulfill his essential contractual or statutory obligations towards" them. It has been concluded that the trial judge is authorized exclusively to determine the issue and to decide whether an employer's obligation is essential (Alrayes \& Alabd, 2017). The employer's main and first obligation has been determined to be paying employees their wages (Bani Khalaf, 2018). In practice, in judgment No. 315/2/432 issued on 3 February 2011, the Superior Commission for the Settlement of Labour Disputes confirmed this provision when it supported the ruling of the Primary Commission for the Settlement of Labour Disputes in Medina No. 188 dated 22 June 2010, and established the principle that the main obligation of the employer was paying wages to employees when due, and if such payment was delayed past the agreed upon time, the employer would be considered in violation of regularly performing his or her contractual obligations. In this case, the employee had 
been dismissed because he was absent for 71 days, but when he sued the employer before the competent authority and showed that the latter had failed to pay his wages on time, the court decided that the justification for the dismissal was invalid and the employee should be returned to his job because the employer had not fulfilled his contractual obligations (The Code of the Labour Principles and Judgments, 2011: pp. 359-367). Similarly, the Superior Commission for the Settlement of Labour Disputes confirmed the ruling of the Primary Commission for the Settlement of Labour Disputes in Jeddah No. 1099 issued on 9 August 2009 and concluded, in judgment No. 228/2/431 dated 10 March 2010, that according to Section 1 of Article 81 of the Saudi Labour Law, the employee is allowed to terminate the work contract if the employer does not pay his wages when due. For this reason, because there was a delay in payment, the employer was obliged to fulfil all the employee's financial rights and pay him a ticket to travel to his own country (The Code of the Labour Principles and Judgments 2010: pp. 303-308). Therefore, an employee whose employer does not pay his or her wages on time may leave his or her job.

In addition to the conclusions described in the previous paragraph, under such circumstances, the non-Saudi employee is authorized to move to another and new employer, provided that the current employer failed to pay his or her wages for three consecutive months. This principle is enacted in Rule 3 of Subsection 8 of Part 2 of Article 14 of the Implementing Regulation for Saudi Labour Law, which also confirms that the same rule is applied if one month's salary has not been paid until the time when the wage of the third month is due. Rules 3 states that in order to apply this provision, the employee should not take any action that leads to the delay in payment; also, he or she must apply his or her demand of working for a new employer to the Minister of Human Resources and Social Development or to an authorized officer within one year from the third month. This rule means that in such circumstances, there is no need to raise an action before the Saudi competent forum in order for the employee to work under the supervision of another employer, as it is sufficient to demonstrate to the Minister of Human Resources and Social Development or to the authorized officer that the required stipulations for applying this provision have been met. In addition, the Decree of the Minister of Human Resources and Social Development No. 111/1 dated 28 January 2007 provides the same principle and adds in Section 2 that under such circumstances, the former employer is obliged to pay all the employee's rights owed for the period before the legal transformation, and pursuant to Section 3 of that Decree, he or she is prohibited from taking any financial compensation from either the new employer or the employee. The Wages Protection System affirmed this ruling, stating that in such situations, the labourer is permitted to work on behalf of another employer without the consent of the former employer, even if the labourer's current working license has not expired (The Ministry of Human Resources and Social Development, 2020b). In judgment No. 8/2/432 issued on 12 December 2010, the Superior Com- 
mission for the Settlement of Labour Disputes affirmed the ruling of the Primary Commission for the Settlement of Labour Disputes in Jeddah No. 481, dated 4 May 2010, concluding that because the employer had failed to pay the employee's wages for six consecutive months, the labourer had the right to sign a new employment agreement with another employer (The Code of the Labour Principles and Judgments, 2011: pp. 311-316). In addition, the Superior Commission for the Settlement of Labour Disputes challenged the ruling of the Primary Commission for the Settlement of Labour Disputes in Hail No. 211 issued on 12 September 2005, which allowed an employee to move to another employer, as the current company had not paid his salary for three consecutive months. The Court of Appeal concluded in judgment No. 1389/1/432 dated 3 October 2011 the principle that the employee did not have the right to move to another company because the payment of his wages was delayed for only two months, not the required three months (The Code of the Labour Principles and Judgments, 2011: pp. 187-194). Hence, a foreign employee may sign a new employment agreement with another employer if his or her current employer does not pay his or her wages for three consecutive months and certain stipulations are met.

Furthermore, an employee is entitled to obtain fair financial compensation for damages incurred if the employer does not pay his or her salary by the due date. This provision has been validated by various judgments issued by the Commission for the Settlement of Labour Disputes. For example, the Superior Commission for the Settlement of Labour Disputes confirmed this concept in judgment No. 36/2/431 dated 13 January 2010, which affirmed the ruling of the Primary Commission for the Settlement of Labour Disputes in Mecca No. 178 issued on 25 April 2009, establishing the principle that employers must pay their financial obligations to their employees when due, and furthermore, when in default without valid justification, the employers are obliged to pay fair compensation to employees for damages sustained (The Code of the Labour Principles and Judgments, 2010: pp. 119-122). Also, in decision No. 1109/2/431 dated 9 November 2010, the Superior Commission confirmed the judgment of the Primary Commission in Medina No. 76 dated 7 March 2010, when it ruled that because the employer had not fulfilled his financial obligation to his employee involving the employee's monthly salary by the due date, he was obliged to pay the employee a certain amount of money as compensation for damages (The Code of the Labour Principles and Judgments, 2010: pp. 369-378). In judgment No. 1457/1/432 issued on 15 October 2011, the Superior Commission for the Settlement of Labour Disputes confirmed the decision of the Primary Commission for the Settlement of Labour Disputes in Riyadh No. 458 issued on 24 January 2010, concluding that the employee was not entitled to obtain a sum of money to which she claimed she was entitled to compensate her for a three-month delay in payment of her wages. The rationale behind this ruling was that the plaintiff raised the issue two years after the date the payment had been delayed, which was found to be an indication that the employee had not suffered any damage relating to the 
delay of salary payment (The Code of the Labour Principles and Judgments, 2011: pp. 363-372). Based on these cases, the competent authority might oblige the employer to pay fair compensation to an employee if the payment of the wages is delayed without valid reasons, provided damages are incurred.

In addition, an employer who does not pay a labourer's wages when due might be fined in accordance with Sections 1 and 2 of Article 94 of the Saudi Labour Law. They establish that in cases when an employer delays the payment of an employee's salary beyond the date due without an acceptable reason, the issue could be raised before the competent authority in order to enforce the employer's obligation to pay the amount in arrears, and if the court is convinced that the justification for delaying the payment is not valid, it may "impose on the employer a fine not exceeding" twice the salary in arrears. Also, according to the rules of the Wages Protection System, the employer who had not paid the salaries of the employees on their determined due date or time, would be penalized by a SR 10,000 fine for every month's delay (The Ministry of Human Resources and Social Development, 2020b). In practice, the Superior Commission for the Settlement of Labour Disputes affirmed, in judgment No. 1305/1/432 issued on 25 June 2011, the decision of the Primary Commission for the Settlement of Labour Disputes in Al-Ahsa No. 128/31 dated 17 March 2010, reemphasizing that the employer must pay labourers' wages on the due date as defined in the Saudi Labour Law. In default, he or she will be fined pursuant to the Law. In this case, the courts decided to financially punish the employer because he had not paid the salaries of 13 employees on time (The Code of the Labour Principles and Judgments, 2011: pp. 401-405). Hence, the competent authority may fine the employer who does not to pay the workers' wages according to the date due.

On the other hand, the rules of Sharia must be considered when examining delayed salary payment to employees in Saudi Arabia because the fixed principle is that the rules of Sharia govern all aspects of regulations in Saudi Arabia, which is confirmed in Article 1 of the Law of Procedures before Shari'ah Courts and Article 48 of the Basic Law of Governance. These articles reemphasize the theory presented in Article 7 of the Basic Law of Governance that "[g]overnance in the Kingdom of Saudi Arabia derives its authority from the Book of God Most High and the Sunnah of his Messenger, both of which govern this Law and all the laws of the State". Also, Article 46 of the Basic Law of Governance sanctions the following: "[ $t]$ here shall be no power over judges in their judicial function other than the power of the Islamic Shari'ah'. Article 4 of the Saudi Labour Law is in line with this provision and upholds that the parties to the employment agreement must abide by the principles of Sharia when they perform the rules of Labour Law. The rules of Sharia related to paying employees' wages are based on various foundations, and one of the main principles is that in the Quran, Allah said "ye who believe! fulfil (all) obligations" (Qur'an 5:1.). In a similar vein, it has been said that pursuant to Islamic rules, the workers' wages should be paid fully as soon as the agreed upon work has been completed without delay and 
without harming the employee (Alsharief, 1977). Also, the parties may agree that wages shall be paid in advance after signing a work contract and before completing the agreed upon work or paying it in instalments (Almarodi, 1994; Ibn Qudamah, 1997). As to the issue of not paying the labourer's wages, Prophet Mohammed said, "it is an act of oppression on the part of a person to procrastinate in fulfilling his obligation" (Al-Bukhari, 2002). Simultaneously, the fixed rule in Islamic jurisprudence is that if damage is incurred, the injured party must be paid a full and fair compensation (AlZuhily, 2012; BouSaq, 2007). This is a mandatory principle, which is obtained from the Prophet's comprehensive statement: "there must be no infliction of damage or reciprocal damage" (BouSaq, 2007). It has been said that this rule is one of the most significant legal maxims of Islamic jurisprudence, and damage must not be caused, but if it has been, it must be corrected, and the victim must be compensated fairly (BouSaq, 2007). Hence, the employer is obliged, in Sharia, to pay labourers their wages on the date due, and in cases when he or she fails to do so, any injured employee is entitled to obtain fair compensation for damage incurred.

Based on the preceding discussion, it can be seen that in cases where an employer fails to pay the employee's wages by the due date, He or she will be regarded as not fulfilled his or her contractual obligations. In such situations, the worker might leave his or her job and is entitled to obtain fair compensation for damages caused. Also, if the employer does not pay him or her wages for three consecutive months, the Saudi Labour Law gives him or her the right to move to another employer. In addition, according to Sections 1 and 2 of Article 94 of the Saudi Labour Law, the competent court may fine the employer in such circumstances.

\section{The Weakness of the Current Approach}

However, an evaluation of the current rules of the Saudi labour Law and the Wages Protection System clearly shows various flaws implied in the approach to dealing with the delayed payment of labourers' wages. The first is that these principles do not address situations that involve the parties to the employment agreement agree to reduce, permanently or temporarily, the worker's wage, during the agreement's validity period, even though an enormous consideration should be given to this point by the parties to the work contract in light of legislation in such circumstances. In addition, although the Wages Protection System requires the employer to submit the total amount of deduction from the employee's wage every month, it seems that it does not offer a clear and practical approach for cases that involve an employer deducting a certain amount of money from an employee's wages for legal reasons and without the consent of the labourer because the employer is legally entitled to deduct certain amount of an employee's wage in specific circumstances and the amount of allowable deduction is defined in general term.

The second concern is an apparent conflict between the rules of the Saudi La- 
bour Law and the principles of the Wages Protection System. Article 93 of the Saudi Labour Law articulates that it is not allowed to deduct a sum of money that "exceeds half the worker's due wage, unless" the competent authority "determines that further deductions can be made or that the worker is in need of more than half his wage. In the latter case, the worker may not be given more than three quarters of his wage". Simultaneously, the principle of the Wages Protection System is that the employer shall be penalized in cases when he or she deducts more than $50 \%$ of the employee's basic salary amount that has been enrolled in the database of the General Organisation for Social Insurance (The Ministry of Human Resources and Social Development, 2020b). The Saudi Labour Law uses three terms to describe labourers' wages: basic wage, actual wage and wage. Pursuant to Article 2 of the Law, in cases when the term "wage" is used in the Law, it means the actual wage, which is defined as follows:

The basic wage plus all other due increments decided for the worker for the effort he exerts at work or for risks he encounters in performing his work, or those decided for the worker for the work under the work contract or work organization regulation. This includes: 1) The commission or percentage from sales or profits paid against what the worker markets, produces, collects or realizes from increased or enhanced production. 2) Allowances the worker is entitled to for exerted effort, or risks he encounters while performing his job. 3) Increments that may be granted in accordance with the standard of living or to meet family expenses. 4) Grant or reward: What the employer grants to the worker and what is paid to him for honesty or efficiency and the like, if such grant or reward is stipulated in the work contract or the work organization regulation of the firm or if customarily granted to the extent that the workers consider it part of the wage rather than a donation. 5) In rem privileges: what the employer commits himself to provide to the worker for his work by stating it in the work contract or the work organization regulation and its estimated at a maximum of two months [sic] basic wage per annum, unless it is otherwise determined to exceed that in the work contract or the work organization regulation.

According to the same Article, the "basic wage" is what is given to an employee "for his work by virtue of a written or unwritten work contract, regardless of the kind of wage or its method of payment, in addition to periodic increments". Hence, it is not clear whether it is allowed to deduct up to half of the worker's wage, which includes multiple allowances, as stated in Article 93 of the Saudi Labour Law, or if the employer shall be punished if the deduction is more than half of the worker's basic salary that is registered with the General Organisation for Social Insurance, as decreed in the Wages Protection System. In other words, it is unclear what amount will be considered in making this determination based on the differing interpretations of the terminology related to "wage".

The third flaw is that neither the Saudi Labour Law nor the Wages Protection 
System provides a specific provision for compensating an employee injured when the employer does not pay his or her wages on the date due. The Wages Protection Program dictates that an employer who fails to pay a worker's wages when due shall be penalized a certain sum of money if the court is satisfied that there were no valid reasons to delay the payment, according to Section 2 of Article 94 of the Saudi Labour Law. Also, the labourer, his or her representative or the Director of the competent Labour Office should raise the issue before the competent authority to enforce the employer's obligation to pay the delayed salary, pursuant to Section 1 of Article 94 of the Saudi Labour Law. In such situations, the Commission for the Settlement of Labour Disputes has established an additional principle that the injured employee might receive fair financial compensation, but to receive such compensation, he or she must, initially, sue the employer and demand the compensation, and the competent courts only have jurisdiction to assess the damage sustained and to determine the fair compensation. This rule must be read in conjunction with the fact that employment wages are, in most cases, the only source of income for the non-Saudi employees in Saudi Arabia.

Fourthly, in cases when the employer does not pay the labourers' wages on the due dates for three consecutive months, applying the recent principles legislated in the Saudi Labour Law and the Wages Protection Program leads to undesirable results for non-Saudi labourers. To explain this point clearly, several points must be highlighted. According to the previous rules, the labourers, regardless of how they receive their wages, whether weekly, monthly or otherwise, are not allowed to move to other and new employers unless the current employer does not pay the due wage for three months consecutively. Consequently, if a company does not pay workers their wages, which are their main, or in most cases, their only source of income, for two months or so, the workers are not legally allowed to work on behalf of a new establishment. At the same time, pursuant to Section 1 of Article 39 of the Saudi Labour Law, without following the required legal principles and procedures, a non-Saudi employee is prohibited from working under the supervision of another employer other than the employer with whom the individual has entered into an employment agreement. Also, according to Article 33 of the law, the non-Saudi labourer must obtain defined permission from the Ministry of Human Resources and Social Development before engaging in any work in Saudi Arabia, regardless of the nature of that work, whether it is "industrial, commercial, agricultural, financial or other work, and any service including domestic service". Various stipulations exist for granting this work license; one of them is that the foreign labourer must sign a work contract with and under the responsibility of a recognisable employer. In addition, Section 2 of Article 39 of the law rules that foreign labourers are strictly prohibited from working on their own behalf, even if their employer permits them to do so. Pursuant to Sections 1 and 2 of the same Article, in cases when foreign employees work on behalf of another sponsor without following the defined procedures, the Ministry 
of Human Resources and Social Development shall, by its inspectors, undertake its duty to seize the employees and refer them to the Ministry of Interior, in order for the deserved punishment to be applied. Moreover, the Ministry of Interior shall assume seizing foreign labourers who are self-employed. It will punish not only them, but also "the employers, work providers, disguisers, transporters and anyone that has a role in the violation". The conclusion of the recent approach is that in cases when the employer delays the payment of salaries, the worker must stay under the sponsor of that establishment for three months, and at the end of the third month, the worker might submit an application to the Ministry of Human Resources and Social Development to work on behalf of another company, provided that the former company continues not paying the salary for three consecutive months. The labourer is not allowed to work on behalf of another employer during this three-month period.

Fifthly, Section 7 of Article 80 establishes the rule that the employer is legally allowed to terminate the employment contract without an end-of-service award, advanced notice or indemnity in cases when the labourer is absent without acceptable reasons for more than 30 days in 1 year or for more than 15 consecutive days, provided that prior to the dismissal, the employee is warned in writing when he or she is absent 20 days in the first case or 10 days in the second case. In such circumstances, the employee has the right to justify objecting to the termination. This rule must be read in conjunction with Article 50 of the Law, which establishes that the employment contract consists of three elements, which are the wage, the work and the employer's management and supervision over the employee's work. Based on these facts, unequal treatment results if the labourer is absent 15 consecutive days, as the employer is authorized to terminate the contract, while the employee is not allowed to move to another company if the employer does not pay his or her wages for two months, unless and until the delay of payments continues for three months consecutively.

The sixth concern with regulations regarding the delay of salary payment is that Section 1 of Article 90 of the Saudi Labour Law establishes the rule regarding how the salary should be paid and states that wages must be paid in accordance with the procedure that determines that the labourer who is "paid on a daily basis shall be paid at least once a week". Also, it states that the employee who is paid on a monthly basis must be given his or her wage once a month. In addition, in cases when "the work is done by the piece and requires a period of more than two weeks, the worker shall receive a payment each week commensurate with the completed portion of the work. The balance of the wage shall be paid in full during the week following delivery of the work". In other cases, the labourers' salary must "be paid at least once a week". When these principles are read in conjunction with the rules established in the Wages Protection System and the Saudi Labour Law, it seems that in some circumstances, the employer is obliged to pay the salary of an employee once a week, but if he or she fails to do so, the migrant labourer is not allowed to legally work on behalf of another es- 
tablishment, as long as the certain stipulation has not been satisfied. In other words, as long as the employer has not delayed payment of wages for three consecutive months, the worker cannot move to other companies, regardless of how his or her salary is paid. Therefore, for employees who are paid monthly, only three payments will have been missed when the employee is legally allowed to work on behalf of another establishment. However, for employees who are paid weekly, approximately 12 wage payments will have been missed when the employee can legally obtain employment elsewhere.

\section{Recommendations for Amending Current Saudi Labour Law}

Based on the previous discussions, it appears that some weaknesses exist in the approaches adopted in the recent rules and procedures in the Saudi Labour Law and the Wages Protection System regarding situations involving an employer who does not pay workers' wages when due. Therefore, it is appropriate to suggest workable approaches to be considered and integrated into the Saudi Labour Law and the Wages Protection System. One suggestion is to require employers, in certain circumstances, to deposit a certain sum of money in an accredited bank in Saudi Arabia or to obtain a letter of guarantee from the bank when the employer runs a business and employs workers. In cases when the employer does not pay labourers' salaries for a defined period, the deposited money or the letter of guarantee might be used to remedy the issue. The required amount of money to be guaranteed should be suitable to the size of the establishment and the number of labourers employed. Secondly, in cases when the payment is delayed, the employee should not be required to raise a case before the competent forum to demand compensation for damages sustained. Instead, it is suitable to integrate into the Saudi Labour Law that upon the delay of payment of workers' wages for a certain period of time, such as a week or so, the employer is obliged to pay a defined percentage of the actual wage as compensation for every week or part of it that the payment was delayed. In this situation, because the trial judge is generally compelled to consult competent experts to evaluate the damages incurred and to assess the fair compensation due to the party harmed (BouSaq, 2007), it is suitable to have an official consultation from financial experts to determine how much the percentage should be. Also, the injured employee should be allowed to raise an action before the competent authority to demand more financial compensation than suggested by the financial experts if the damage caused is great. The concept of integrating the compensation into the Labour Law for the same situation has been accepted in some states. For instance, Section 3 of Article 40 of the Bahraini Labour Law articulates the following:

[I]f the employer shows delay in the disbursement of the worker's wage, said employer shall pay to the worker an annual compensation equivalent to $6 \%$ of the wage in respect of which a delay was shown during six months 
or less as of the date of payment of the wage. This rate shall be subject to a $1 \%$ increase for each month of delay after said period without exceeding

$12 \%$ of the wage per year.

The fact is that fair compensation should be also given to the employee in cases when he or she receives wages less than what was agreed upon because the employer is not allowed to deduct any amount of money from the employee's wage without valid justification. Thirdly, in cases when the employer does not pay a monthly salary for more than one month or a weekly salary for two consecutive weeks, the foreign labourer should be allowed legally to move to another establishment ${ }^{5}$. This suggestion could be supported by the judgment of the Superior Commission for the Settlement of Labour Disputes No. 228/2/431 issued on 10 March 2010 that confirmed the ruling of the Primary Commission for the Settlement of Labour Disputes in Jeddah No. 1099 dated 9 August 2009. In this case, it was concluded that because there was a delay of payment of the employee's wage for at least 20 days, the employer was regarded as having failed to fulfil his essential obligations to pay the employee's salary at the end of each month, and therefore, stoppage of work by the employee was lawful. The courts also concluded that the employer was obliged to pay a ticket for the employee to return home (The Code of the Labour Principles and Judgments, 2010: pp. 303-308). In this case, the court established the principle that because the payment of the labourer's wage had been delayed for more than 20 days, termination of the employment agreement by the employee was lawful conduct, so it is logical to say that in such circumstances, the employee should have the right to leave the country or to sign a new work contract with another employer. In addition, it is suitable to revise the rules of Wages Protection System regarding the point of how much it may deduct from the employees' wages and it is appropriate to maintain the rule established in article 93 of the Saudi Labour Law that it is not authorized to deduct a sum of money which exceeds half the employee's due wage, unless the competent authority "determines that further deductions can be made or that the worker is in need of more than half his wage. In the latter case, the worker may not be given more than three quarters of his wage". Finally and importantly, in cases where the parties have agreed to reduce the employee's wage, during the agreement's validity period, the details of the agreement must be performed via the Wages Protection System. This recommendation would be supported by the judgments of the Superior Commission for the Settlement of Labour Disputes No. 1508/1/431 issued on 9 August $2010 \mathrm{H}$ (The Code of the Labour Principles and Judgments, 2010: pp. 321-327), No. 674/1/431 dated 5 April 2010 (The Code of the Labour Principles and Judgments, 2010: pp. 347-357) and No. 305/2/431 issued on 31 March 2010 (The Code of the Labour Principles and Judgments, 2010: pp. 281-285). In these judgments, the forum

\footnotetext{
${ }^{5}$ The UAE has applied the similar concept for companies employing more than 100 employees and it has been stated that in case where such a company fails to pay employees' wages for more than one month, the employees will be authorized to move to other employers (The Official Portal of the Government of the United Arab Emirates, 2020).
} 
confirms the rule that the employee's wage shall not adjusted or reduced while the employment agreement is in effect without the employer's and employee's consent and approval. At the same time, in cases when the employer is legally allowed to deduct a certain amount from the employee's wage, without his or her consent, for an acceptable reason, the employer should not only submit the "total amount of deduction", but also written justification for the deduction must be done through the Wages Protection System. This is because the amount of deduction is defined generally in the law and the employer is not allowed to deduct more than the maximum amounts specified in the law.

\section{Conclusion}

In conclusion, there are a huge number of migrant labourers working in the private sector in Saudi Arabia and the employment wages are a vital source of income for them. This paper presented an analysis of how the Saudi Labour Law and the Wages Protection System address the issue of delayed payment of workers' wages and the flaws implied in this approach have been illustrated. At the same time, it focused briefly on the rules enacted in the Saudi Labour Law that protect labourers' wages. The research presented herein shows that although the current rules provide appropriate protection for labourers' wages, there are various flaws that were revealed. For this reason, as suggested in this study, several practical approaches should be integrated into the Saudi Labour Law and the Wages Protection System. Through the previous discussions, a number of remarkable findings have been concluded that are introduced below, followed by recommendations for future studies.

The evidence presented in this paper clearly indicates that payment of employees' wages is the employer's main and essential obligation toward workers under employment contracts, and there is no doubt that unpaid work falls outside the scope of the jurisdiction of the Saudi Labour Law because Article 50 of the Law provides that the employment agreement is "a contract concluded between an employer and a worker, whereby the latter undertakes to work under the management or supervision of the former for a wage". Also, Section 1 of Article 81 entitles the labourer to end the work contract without giving notice to the employer and without hurting his or her statutory rights "if the employer fails to fulfill his essential contractual or statutory obligations towards" him or her.

The Saudi Labour Law includes proper provisions to protect labourers' salaries. For example, the method of payment of the wages agreed to by the parties to the employment agreement, whether monthly, weekly or otherwise, cannot be changed without the consent of the employee. Similarly, the employer is not authorized to deduct from the labourer's wages against private financial rights without the labourer's written approval, unless under certain situations defined in the Law. In cases when the employer deducts any certain sum of money from the employee's wages without valid justification, the employer may face a finan- 
cial penalty as determined by the competent authority. Also, in cases of an enterprise's bankruptcy, its employees' financial rights shall be considered privileged debts.

The Wages Protection System, which was launched on 1 June 2013 and went into effect on 1 September 2013, is regarded as an advanced and helpful governmental system to monitor the process of payment of employees' wages in the private sector. Through this program, employers are obligated to submit specific documents on a monthly basis to verify that they pay their workers' wages according to what was agreed to by the parties in their employment agreements. Moreover, the employer shall be punished in cases when a salary deduction is greater than $50 \%$ of the employee's basic wage enrolled in the General Organisation for Social Insurance or in cases when the basic salary of the labourers submitted in the program are not equal to what has been recorded in the General Organisation for Social Insurance.

In cases when an establishment fails to pay an employee his or her wages on the date due, the rules in Saudi Law are that the employer might be fined by the competent court because of the delay of payment. The judgments issued by the Commission for the Settlement of Labour Disputes reemphasize that the employer must pay the wages when due, and when in default, the employer might be punished. Also, the labourer can leave the job and return to his or her home country. Moreover, in cases when the employee is harmed, he or she may sue the employer before the competent authority and demand financial compensation for damages sustained. In addition, the foreign employee is legally allowed to move to a new company, provided that the delay of payments continued for three consecutive months.

Several concerns are noted regarding the Saudi Labour Law and the Wages Protection System relating to the issue of not paying employees' salaries by the agreed upon date. One of them is that the regulations do not define the process for compensating the worker when his or her wages are not paid on time, although the Commission for the Settlement of Labour Disputes has confirmed, in several issued judgments, that the employee is entitled to receive fair compensation if it is satisfied that he or she suffered damage resulting from the delay of wage payment. This means that in such situations, in spite of the fact that the salary is likely the main source for living for the worker and his or her family, in particular when he or she is non-Saudi, the employee should, initially, sue the employer before the competent court, which must be convinced that the labourer suffered damage. In addition, the migrant labourer shall not be allowed to move to another company unless the employer does not pay his or her wages for three consecutive months, even if the parties agreed for the wage to be paid weekly. In this three-month period, the employee is strictly prohibited from working on behalf of another establishment or from being self-employed. Otherwise, he or she shall be penalized severely by the Ministry of Human Resources and Social Development and by the Ministry of Interior. Also, there is no straightforward and precise approach to regulate the issue that the parties to the employment 
contract have agreed to reduce the labourer's wage, during the contract's validity period. Furthermore, the rules of the Saudi Labour Law and the provisions of the Wages Protection System conflict on the point of how much it may deduct from the employee's wage. According to the Wages Protection System, an employer who deducts more than $50 \%$ of the employee's basic salary enrolled in the databases of the General Organisation for Social Insurance shall be punished, while Article 93 of the Saudi Labour Law provides that it cannot deduct more than $50 \%$ of the employee's wage, and according to Article 2 of the Saudi Labour Law, when the term "wage" is used in the Saudi Labour Law, it means the actual wage, which includes many allowances, in addition to the basic wage.

It is suitable to adjust and to update the recent rules of the Saudi Labour Law and the Wages Protection System relating to the point of not paying the labourers' wages on due dates. Several approaches should be considered. Firstly, in cases when a company wants to employ workers, it should be mandatory, in certain situations, to lay down a certain amount of money in a Saudi bank or to obtain a letter of guarantee from an acceptable financial institution, such as a bank. Then, if the company fails to pay the employees' salaries when due, the money deposited and the letter of guarantee could be used to address the issue. Secondly, it is appropriate to set up the rule that the employer is obliged to pay a certain percentage of the actual labourer's wage as compensation to the labourer in cases when he or she does not pay the employee's salary when due and the calculation of the compensation depends on the amount of the salary and how many weeks the payment of wage is delayed. The employee could demand additional compensation before the competent court if the damage incurred is huge. He or she should also have the right to obtain the financial compensation if the wage received is less than what had been agreed upon without acceptable reasons. Thirdly, the migrant employee should have the authority to work under the sponsor of another employer as soon as it has been approved that the current company has not paid his or her wage for more than one month, provided that the salary is paid every month according to legal requirements, but if the parties agreed for payment to be made once a week, as regulated in Article 90 of the Saudi Labour Law, it is suitable for the employee to be allowed to move to another establishment if wages were not paid for two consecutive weeks. Also, it is appropriate to revise the provision of Wages Protection System relating to the issue of how much it could deduct from the workers' wages and sustain the principle enacted in Article 93 of the Saudi Labour Law that it is not allowed to deduct a sum of money which exceeds half the worker's due salary. Finally, the parties to the employment contract should be permitted to sign a temporary or permanent agreement to reduce a certain percentage from the workers' wage, provided that all the documents and procedures related to this recommendation must be done through the Wages Protection System. Simultaneously, if the employer is allowed legally to deduct a certain amount from the employee's wage, without the consent of labourer, he or she should provide the reasons for deducting to the Ministry of Human Resources and Social Development via the 


\section{Wages Protection Program.}

Some recommendations for future study were identified during this research process. More research should be done to determine whether an employee who stops working because his or her wages were not received by the date due deserves to obtain a wage for the days he or she did not work. The reason for this is that the fixed principle in the Saudi Labour Law is that if the employee does not perform actual work in a day, he or she does not deserve to receive any sum of money as a wage for that day, which the Superior Commission for the Settlement of Labour Disputes affirmed in judgment No.1559/1/431 on 21 August 2010 (The Code of the Labour Principles and Judgments, 2010: pp. 289-295). Article 62 of the Law might provide an acceptable solution in such situations, as it states, "[i]f the worker reports to work on the prescribed time or expresses his readiness to perform his work at such times but is prevented from doing so only by a cause which is ascribed to the employer, the worker shall be entitled to the wage for the period during which no work is performed".

\section{Conflicts of Interest}

The author declares no conflicts of interest regarding the publication of this paper.

\section{References}

Al Riyadh Newspaper (2018). 42,418 Establishments Enrolled in Protecting Wages System Last Year. Al Riyadh Newspaper, 18 March 2018.

http://www.alriyadh.com/1669393\#

Al-Bukhari, M. (2002). Sahih Al-Bukhari. Damascus: Dar Ibn Katheer.

Almarodi, A. (1994). Alhawi Alkabir(Vol. 9). Beirut: Dar Alfeker.

Almutairy, M. (2019). A Private Company to Manage the Wages of the Employees in the Private Sector at the End of 2020. Al Eqtisadiah Newspaper, 4 July 2019.

http://www.aleqt.com/2019/07/04/article 1630871.html

Almuzaini, S. (1989). The Wage in Saudi Labour Law. Diploma Thesis, Riyadh: Institute of Public Administration.

Alolyan, F. (1988). The Wage in the Employment Contract: A Comparative Study. Diploma Thesis, Riyadh: Institute of Public Administration.

Alrayes, R., \& Alabd, R. (2017). Describing the Legislation of Saudi Labour Law in Accordance with the Amendments Issued by the Royal Decree No. M/46 Dated on 5/6/1436 $H$ (25 March 2015) (2nd ed.). Riyadh: Al-Shegrey for Publishing and Information Technology.

Alsharief, S. (1977). The Leasing on Human Labour: A Comparative Study. Ph.D. Thesis, Jeddah: King Abdulaziz University.

Alzahrani, A. (2019). 80 Workers Complain of Not Paying Their Wages for 12 Months. Al Madina Newspaper, 7 February 2019. https://www.al-madina.com/article/613702

AlZuhily, W. (2012). The Theory of Guarantee or the Provisions of Civil and Criminal Liability in Islamic Jurisprudence: A Comparative Study (9th ed.). Damascus: Dar Al Fikr.

Asian Development Bank Institute; Organisation for Economic Co-Operation and Development; International Labour Organization (2019). Building Partnerships for Effectively Managing Labour Migration: Lesson from Asian Countries. Tokyo: Asian De- 
velopment Bank Institute.

https://www.ilo.org/wcmsp5/groups/public/---asia/---ro-bangkok/documents/publicati on/wcms 682156.pdf

Badewilan, B. (2017). 30\% of the Establishments Do Not Comply with the Rules of the Protection of Wages and the Labour Ministry Threatens to Suspend All Their Services. Al Madina Newspaper, 12 October 2017. https://www.al-madina.com/article/543839

Bani Khalaf, H. (2018). The Intermediary for Explaining the Saudi Labour Law in Light of the Principles and Judgments of the Labour Disputes Settlement Body. Riyadh: International Publishing House.

Ben Ghunaim, S. (2000). The Legal Protection for Wage in Saudi Law. Diploma Thesis, Riyadh: Institute of Public Administration.

BouSaq, M. (2007). The Compensation for Damage in Islamic Jurisprudence (2nd ed.). Riyadh: Dar Konoz Eshbilia for Publishing and Distribution.

Hadfy, B. (2015). The Brief in Explanation of Labour Law: An Individual Labour Relationship (3rd ed.). Algiers: Joussour for Publication and Distribution.

Hamdan, H. (2009). The Labour Law: A Comparative Study. Beirut: Halabi Legal Publications.

Ibn Qudamah, A. (1997). Almukhni (Vol. 8). Riyadh: Dar Alam Alkutub.

Shah, N. (2008). Recent Labor Immigration Policies in the Oil-Rich Gulf: How Effective Are They Likely to Be? ILO Asian Regional Programme on Governance of Labour Migration, Working Paper No. 3, Bangkok: International Labour Organization.

https://www.ilo.org/wcmsp5/groups/public/---asia/---ro-bangkok/documents/publicati on/wcms 099165.pdf

The Code of the Labour Principles and Judgments (2010). Vol. 1, The General Directorate of the Commission for the Settlement of Labour Disputes, Superior Commission for the Settlement of Labour Disputes (pp. 119-122, 289-295). Riyadh: The Ministry of Human Resources and Social Development.

The Code of the Labour Principles and Judgments (2010). Vol. 2, The General Directorate of the Commission for the Settlement of Labour Disputes, Superior Commission for the Settlement of Labour Disputes (pp. 281-285, 303-308, 321-327, 347-357, 369-378). Riyadh: The Ministry of Human Resources and Social Development.

The Code of the Labour Principles and Judgments (2011). Vol. 2, The General Directorate of the Commission for the Settlement of Labour Disputes, Superior Commission for the Settlement of Labour Disputes (pp. 311-316, 363-372, 401-405). Riyadh: The Ministry of Human Resources and Social Development.

The Code of the Labour Principles and Judgments (2011). Vol. 3, The General Directorate of the Commission for the Settlement of Labour Disputes, Superior Commission for the Settlement of Labour Disputes (pp. 187-194, 359-367). Riyadh: The Ministry of Human Resources and Social Development.

The General Authority for Statistics (2019). Employed, Fourth Quarter. https://www.stats.gov.sa/sites/default/files/lm-2019-q4-0.xlsx

The Ministry of Human Resources and Social Development (2020a). Strategic Objectives, Strategic Objectives for National Transformation Program.

https://mlsd.gov.sa/en/page/strategic-objectives

The Ministry of Human Resources and Social Development (2020b). Wages Protection System.

https://mlsd.gov.sa/ar/initiatives/\%D8\%A8\%D8\%B1\%D9\%86\%D8\%A7\%D9\%85\%D8\% AC-\%D8\%AD\%D9\%85\%D8\%A7\%D9\%8A\%D8\%A9-\%D8\%A7\%D9\%84\%D8\%A3\%D 8\%AC\%D $\% 88 \% \mathrm{D} 8 \% \mathrm{~B} 1$ 
The Official Portal of the Government of the United Arab Emirates (2020). Payment of Salaries (Wages).

https://www.government.ae/ar-ae/information-and-services/jobs/payment-of-wages

The Saudi Council of Economic and Development Affairs (2018). The Operational Plan for the National Transformation Program 2018/2020.

https://www.vision2030.gov.sa/sites/default/files/attachments/NTP\%20Arabic\%20Publi c\%20Document $\% 202810$ 0.pdf

The US-Saudi Arabian Business Council (2017). Working in Saudi Arabia: A Labor Market Update. Labor Market Industry Brief, Vienna: The US-Saudi Arabian Business Council.

http://www.ussaudi.org/wp-content/uploads/2018/02/Labor-Industry-Brief-2017.pdf 